\title{
DOES JOB INSECURITY AFFECT HOUSEHOLD CONSUMPTION?
}

Andrew Benito

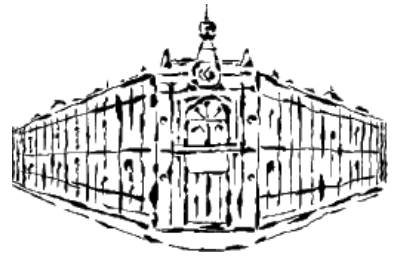

Banco de España - Servicio de Estudios

Documento de Trabajo n. ${ }^{\circ} 0225$ 


\title{
Does Job Insecurity Affect Household Consumption?
}

\author{
Andrew Benito* \\ Banco de España
}

31 October 2002

Acknowledgements: I am especially grateful to Olympia Bover and Garry Young for comments on an earlier draft as well as seminar participants at the Bank of Spain. The data employed were originally collected by the ESRC Research Centre on Micro-Social Change at the University of Essex. Neither the original collectors of the data nor the Data Archive bear any responsibility for the analyses presented here. The paper represents the views and analysis of the author and should not be thought to represent those of the Bank of Spain.

JEL Classification: D12, E21.

Key Words: Consumption; precautionary saving; job insecurity.

${ }^{*}$ Address: Bank of Spain Research Department, Calle de Alcalá 50, 28014 Madrid, Spain. Tel: +34 91 338 5277. E-mail: andrew.benito@bde.es 


\begin{abstract}
:
The paper confronts a key implication of the precautionary model of saving/consumption, using micro-data on British households. The results provide support for the key proposition that job insecurity affects consumption. A one standard deviation increase in unemployment risk for the head of household is estimated to reduce consumption by 2.7 per cent. This effect is greater for the young, those without non-labour income and manual workers-for whom precautionary effects might be expected to be stronger a priori. Consumer durables purchases are also found to be inversely related to unemployment risk.
\end{abstract}




\section{Introduction}

The risk of job loss represents a major source of income uncertainty facing most households. The hypothesis that such uncertainty gives rise to a precautionary motive for saving has been put forward as a significant development of the standard life-cycle model of consumption (eg. Carroll (2001), Caballero (1990)). Such models of precautionary saving have many attractive features. In principle, they appear able to account for a number of stylised facts associated with consumption patterns and the life-cycle, such as the apparent excess sensitivity of consumption to anticipated income, that the canonical life-cycle model cannot explain. ${ }^{1}$ However, the relatively few attempts that have been made to identify evidence of a precautionary motive have produced mixed results. Although Carroll et al. (1999) and Lusardi (1998) find evidence supporting the basic proposition, other studies find little or no such evidence (eg. Dynan (1993), Starr-McCluer (1996)).

The issue of job insecurity has also attracted increasing attention, particularly in Britain. This has been partly motivated by the apparently large increases in perceived job insecurity despite relatively small movements in separation rates (Nickell et al. (2002)). But what are the effects of job insecurity? Might job insecurity affect consumption behaviour as implied by the precautionary motive for saving? The issue also has important implications for the aggregate behaviour of consumption and conditions in the labour market. Carroll and Dunn (1997) examine the time-series behaviour of US consumption and unemployment expectations and argue that the latter have played a key role in the cyclical behaviour of consumers' expenditure and the US economy.

The present paper confronts a key empirical implication of the precautionary model of consumption with micro data for British households. Specifically, the hypothesis considered is whether consumption levels are related to job insecurity. ${ }^{2}$ As noted above, there have been relatively few previous attempts to consider this question, none of which use data for Britain. Closest in spirit to the present paper are the studies by Carroll et al. (1999) and Lusardi (1998). Carroll et al. (1999) construct individual-level predicted probabilities of job

\footnotetext{
${ }^{1}$ Pemberton (1997) for instance, calibrates the standard life-cycle model under perfect capital markets and argues that the results are inconsistent with basic stylised facts of consumption.

${ }^{2}$ The use of the term job insecurity here refers specifically to the likelihood of job loss. Nickell et al. (2002) discuss other interpretations including wage flexibility.
} 
loss and include this variable in models for savings finding significant evidence of additional saving by those households whose head of household faces greater job insecurity. Lusardi (1998) instead employs a self-reported likelihood of job loss for a sample of men close to retirement in the United States with results indicating that saving is positively related to the indicator of job insecurity. The present paper borrows from both approaches, employing a model-based predicted likelihood of job loss and subjective job insecurity measure for households in Britain from the British Household Panel Survey and considers a role for these variables in influencing household-level consumption. The key contribution is to provide evidence of significant precautionary saving effects associated with unemployment risk in shaping non-durable consumption for households in Britain for the first time. More specifically, the estimates imply that a one standard deviation increase in unemployment risk lowers consumption by 2.7 per cent. This effect is estimated to be stronger among the young, those without non-labour sources of income and manual workers, as we might be led to expect a priori. Moreover, a further contribution is to provide evidence that consumer durables purchases are inversely related to unemployment risk.

The remainder of the paper is organised as follows. Section 2 provides some further economic and theoretical background to the paper. Section 3 sets up the econometric model and presents the hypotheses of interest. Section 4 discusses the data and estimation results derived from the British Household Panel Survey. Section 5 concludes.

\section{Economic background}

Precautionary saving models extend the standard life-cycle approach to allow for undesirable (and uninsurable) income uncertainty. ${ }^{3}$ A result of Caballero (1990) illustrates the role of uncertainty and precautionary saving most neatly, by assuming the within-period utility function is exponential. With (constant) coefficient of absolute risk aversion $\kappa$, this is $U\left(c_{t}\right)=-\frac{1}{\kappa} \exp \left(-\kappa c_{t}\right)$, where $c$ is consumption. It is further assumed that income, $y$, takes the form $y_{t}=\lambda y_{t-1}+(1-\lambda) \widehat{y}+\varepsilon_{t}$, where $\varepsilon_{t} \sim i i d\left(0, \sigma^{2}\right), \widehat{y}$ is the deterministic component of income and $\lambda$ measures the degree of persistence in income shocks, $\varepsilon_{t}$. The

\footnotetext{
${ }^{3}$ More specifically, the precautionary motive arises from a positive third derivative of the utility function. This precludes the case of a quadratic utility function combined with labour income uncertainty, which gives rise to the standard certainty equivalence result.
} 
consumer chooses a path for consumption maximising expected intertemporal utility from consumption subject to the income process and the budget constraint, $w_{t}=R_{t} w_{t-1}+y_{t}-c_{t}$., where $w_{t}$ is end-of-period $t$ wealth and $R$ is the interest factor $(1+r)$.

Caballero (1990) shows that the solution to this problem is the sum of two components. The first component is the certainty equivalence level of consumption, whilst the second is that associated with the precautionary motive for saving. ${ }^{4}$ When the income shock is normally distributed, this latter term simplifies to $\kappa \sigma^{2} /(R-\lambda)$ such that precautionary saving is increasing in the variance of shocks to income, $\sigma^{2}$, the degree of persistence of income shocks, $\lambda$, and the degree of risk aversion, $\kappa .^{5}$ The level of consumption is decreasing in each of these terms. The assumption of exponential utility is of course, restrictive, but under more general conditions it can be shown that greater income uncertainty lowers the optimal level of consumption. Skinner (1988) assumes the one-period utility function takes the constant relative risk aversion (CRRA) form in place of the constant absolute risk aversion (CARA) form used by Caballero (1990). Again the result obtains that optimal consumption is a negative function of income uncertainty. This result is also found using numerical methods by Zeldes (1989) for the CRRA case. It is the key message from the literature on precautionary savings and consumption that we wish to confront with data. ${ }^{6}$

A number of empirical attempts exist at confronting this message from the literature on the precautionary motive for saving. Carroll et al. (1999) estimate models for the individual probability of unemployment for a sample of US households, relating saving behaviour to this variable and find evidence of a significant precautionary effect at modest and higher levels of income. Guiso et al. (1992) employ Italian household-level survey data including self-reported earnings uncertainty and also find evidence consistent with the basic

\footnotetext{
${ }^{4}$ This is when $r=\delta$ where $\delta$ is the rate of time preference. When $r \neq \delta$, the consumption function may still be decomposed into two components, one of which relates to precautionary saving but the other component is not the certainty equivalence level.

${ }^{5}$ Under exponential utility, the coefficient of absolute risk aversion, $\kappa$, coincides with the degree of prudence, defined as the ratio of the third to the second derivative of the within-period utility function (Kimball, 1990). One unattractive feature of this function is that it does not rule out negative consumption.

${ }^{6}$ In models of precautionary saving such as Carroll (1992), it is the probability of a near-zero income that is the key determinant of the precautionary saving motive. Carroll (1992) suggests that unemployment comes closest to such an event. This provides a further link between these models and the use of the probability of job loss as the relevant measure of labour income uncertainty below. Earlier models include Sandmo (1970).
} 
hypothesis.

For the UK, Miles (1997) and Guariglia and Rossi (2002) find evidence of precautionary motives at work based on constructing estimates of the income risk facing households and including these in household consumption functions or Euler equation in the case of Guariglia and Rossi (2002). For the measure of income risk, Miles (1997) uses the squared residual from an income equation whilst Guariglia and Rossi (2002) employ the variance of each household's residual over the three years (or more, depending upon the number of observations per household and year in question) up to year $t$. The squared residual employed by Miles (1997) could pick up any convexity whilst basing a variance measure on as few as three observations, as in Guariglia and Rossi (2002), (and with the number of observations varying across households and time) is clearly problematic. Banks et al. (2001), adopt an approach based on the construction of a cohort-based quasi-panel, which distinguishes between cohort-specific and common income risks. Their results find strong evidence of precautionary saving, in particular associated with the cohort-specific income risk component. This paper instead focuses exclusively on unemployment risk of the household head as the source of risk facing the household, in part in order to understand the effects of job insecurity.

The relation between consumer durables purchases and unemployment expectations is considered by Carroll and Dunn (1997) using aggregate US data. As a basis to their analysis, they develop an $(\mathrm{S}, \mathrm{s})$ model of consumer durables purchasing with a role for income uncertainty. In this framework an increase in unemployment risk leads to the postponement of the purchase of consumer durables as households instead opt to add to their precautionary assets which are used as a buffer-stock. That is, the lower trigger of the (S,s) rule for the ratio of the value of durable goods to permanent labour income falls. Households instead wish to accumulate more savings which they use as a buffer against the higher level of uncertainty resulting from job insecurity. ${ }^{7}$ In this way, those facing greater job insecurity

\footnotetext{
${ }^{7}$ The value of consumer durables depreciates over time, whilst permanent income grows over time, such that the ratio of the value of durables to permanent labour income drifts downwards. When the ratio has fallen sufficiently, it is optimal to make a purchase. An increase in labour income uncertainty raises the marginal utility of precautionary assets held as a buffer against uncertainty, such that the durables purchase decision is delayed. This model is related to, but remains quite different from, the notion that uncertainty increases the 'option value' of waiting.
} 
should be less likely to have recently purchased household consumer durables, controlling for other demographic characteristics of the household. This is an additional hypothesis confronted with data below.

\section{Estimation strategy}

In order to address the basic hypothesis-that household consumption levels are a function of job insecurity-there are a number of econometric issues to be confronted. The estimation strategy is largely geared towards addressing these issues which relate to the construction of permanent income from cross-sectional data, the grouped nature of the data on consumption and identification.

The basic model for consumption involves estimating a consumption function of the following form:

$$
c_{i t}=\alpha+\theta_{1} y_{i t}^{P}+\theta_{2} y_{i t}^{T}+\theta_{3} y_{i t}^{W}+\delta \widehat{u}_{i t}+X_{i t} \beta+\gamma_{t}+\varepsilon_{i t}
$$

where $i$ indexes individuals (heads of household), $i=1,2 . . \mathrm{N}$ and $t$ indexes waves of the survey, $t=1992 \ldots 1998 . c$ is $\log$ household consumption, $y^{P}$ is permanent labour income, $y^{T}$ is transitory labour income and $y^{W}$ is investment income. ${ }^{8} \widehat{u}$ is the measure of job insecurity. This consists of either the subjectively-perceived degree of job insecurity or a predicted risk of job loss. $X_{i t}$ represents a vector of regressors with associated parameter vector, $\beta$. The regressor set $X$ includes controls for household and head of household demographics (family size, composition, educational attainment etc., see Table 3 for more details). ${ }^{9} \gamma_{t}$ denotes a set of common year effects with error term, $\varepsilon_{i t}$.

\section{Permanent Income}

The standard definition of permanent income is the annuity value of the sum of the present discounted value of expected future labour income (ie. human wealth) and non-human wealth. Following King and Dicks-Mireaux (1982) and Guiso et al. (1992)

\footnotetext{
${ }^{8}$ The income terms are considered in levels rather than logs since transitory income takes on negative values. Consumption is considered in logs since in levels its distribution is skewed.

${ }^{9}$ The head of household is defined as the principal owner or renter of the property and (where there is more than one) the eldest takes precedence.
} 
permanent labour income $y^{P}$, is defined as normal (weekly) labour income adjusted for age and cohort effects. Transitory income $y_{i t}^{T}$, is defined as the difference between current and permanent labour incomes. Non-human wealth is not measured explicitly here and its role is captured through the investment income term, $y^{W}$, as in Miles (1997). ${ }^{10}$ Note that this excludes housing wealth.

Permanent income differs from current household income for various reasons and in particular through life-cycle effects and transitory income differentials. The calculation of permanent income involves taking the predicted values from a random effects equation for $\log$ household labour income as a function of a range of household demographic variables and then obtaining a 'permanent' value from a projection of this value forwards until retirement (assumed 65 for men, 60 for women) for each household also using estimates of how household incomes vary with age. Estimates of this differential obtained from crosssectional data conflate the age effect with a cohort effect (Shorrocks, 1975) since in any cross-section older household heads also belong to earlier cohorts, who have lower lifetime income owing to productivity growth. In order to separate out the cohort- from the ageeffect, separate evidence from Benito (2001) on the magnitude of the age effects is used. The estimation of the age effects did not restrict the form of the effects, instead using separate age dummies in a cohort/age quasi-panel constructed from Family Expenditure Survey data for the years 1972 to $1998 .^{11}$ This is clearly much less restrictive than the approach of Guiso et al. (1992) and Miles (1997) both of which imposed a quadratic relation in age. Mean (median) weekly permanent income (1995 prices) is calculated as £438.74 (£401.61), transitory income, $£ 62.15$ (£50.97) and investment income $£ 12.26(£ 2.20) .{ }^{12}$

The form of estimating equation is similar to that of Carroll (1994) and Guiso et al. (1992) who use Italian household data focusing on the impact of a self-reported measure of earnings uncertainty on consumption. The use of consumption data for the dependent variable avoids specification issues arising in studies that have employed net worth data as the dependent variable, in particular where this possesses negative values but a log

\footnotetext{
${ }^{10}$ Non-human wealth would equal $y^{W} / r$ where $r$ is the instantaneous interest rate.

${ }^{11}$ For a description of pseudo-panel methods, see also Attanasio (1999). The identifying restriction imposed consisted of assuming that the year effects for the period 1972 to 1998, intended to reflect cyclical factors, averaged zero. The age and cohort effects on income were unrestricted.

${ }^{12}$ The definition of transitory income does not require that it is mean zero.
} 
specification seems justified. ${ }^{13}$ Data for specifically food and groceries expenditures would not be the preferred measure of consumption. However, as in studies such as Guariglia and Rossi (2002), Kuehlwein (1991) and Hall and Mishkin (1982), its use can be justified as an empirically important component of non-durable expenditure and by an assumption of separability of utility from food and other forms of consumption. Nevertheless, to the extent that uncertainty leads households to cut back on expenditures and in particular on those items that are not essentials, the use of food and grocery expenditure as the dependent variable will bias the results against finding evidence of precautionary saving. Further analysis below will also consider the relation between consumer durables purchases and unemployment risk. ${ }^{14}$

The sole previous attempt to estimate a consumption function of this form on British or UK data is that by Miles (1997) who employed separate waves of the Family Expenditure Survey (FES). Miles (1997) estimated an elasticity of consumption with respect to household permanent income of 0.82 and with respect to transitory income of 0.61 . Note that in the present case the dependent variable consists of a subset of all consumption, namely that on food and groceries for which an the elasticity with respect to permanent income should be expected to be well below unity. The discussion of precautionary saving motivates the consideration of the further hypothesis, $H_{o}: \delta=0$ versus $H_{A}: \delta<0$, under precautionary saving, which will be the focus of attention here.

\section{Grouped consumption data}

The data on consumption are grouped, specifying a particular interval or range for the level of weekly expenditure on food and groceries. ${ }^{15}$ Use of grouped data raises particular estimation issues. To explicitly allow for this, a maximum likelihood method is

\footnotetext{
${ }^{13}$ King and Dicks-Mireaux (1982) for instance, dropped observations where annual earnings were less than $\$ 2,500$. This is likely to introduce a substantial sample selection effect although they do attempt to correct for it; Carroll et al. (1999) adopt an inverse hyperbolic sine functional form for this reason.

${ }^{14}$ Carroll (1992, p.107) reports results suggesting that aggregate food consumption in the US is as sensitive to unemployment expectations as total non-durable expenditures. Browning and Crossley (1999) find that households cut back on 'small' durables (eg. clothing) to a greater extent than food during an actual unemployment spell.

${ }^{15}$ The bands are the following: below $£ 10 ; £ 10$ to $£ 19 ; £ 20$ to $£ 29 ; £ 30$ to $£ 39 ; £ 40$ to $£ 49 ; £ 50$ to $£ 59$; $£ 60$ to $£ 79$; 80 to $£ 99 ; £ 100$ to $£ 119 ; £ 120$ to $£ 139 ; £ 140$ to $£ 159$; above $£ 160$.
} 
employed that allows for the fact that the actual level within each band (with one openended category) is unobserved (see Stewart, 1983). A common alternative, that of using the mid-points to the bands, and then treating the variable as if it were continuous, will not in general provide consistent parameter estimates. This latter approach is adopted by Guariglia and Rossi (2002) in estimating Euler equations by GMM using BHPS data. The grouped dependent variable (GDV) estimator has been used most extensively in studies of earnings determination where, in British survey data, this has often been grouped into intervals (eg. Stewart, 1990). ${ }^{16}$

This paper employs two approaches to consider the hypothesis $\delta=0$. These approaches differ in their construction of the unemployment expectations or job insecurity term, $\widehat{u}$. The first approach takes head of household responses to a question in the BHPS of all employed individuals concerning the likelihood that they will become unemployed in the next twelve months (see below for further details). This is straightforward to implement. The second approach estimates the individual probability of becoming unemployed in twelve months for the sample of employed heads of households. This is derived as the predicted probability from a probit model:

$$
u_{i t}=1\left\{Z_{i t} \varpi+v_{i t}>0\right\}
$$

where $1\{A\}$ is an indicator function of the event $A$ such that $u_{i t}=1$ if the individual becomes unemployed at the time of the subsequent BHPS interview and zero otherwise. The set of regressors, $Z_{i t}$ includes a set of regional and year dummies to control for regional and aggregate effects as well as the other individual and household characteristics contained in $X_{i t}$ in (1). Under the probit assumption, $v_{i t} \sim N\left(0, \sigma_{u}^{2}\right)$, the predicted probabilities are then calculated as $\Phi\left(Z_{i t} \widehat{\varpi}\right)$ where $\Phi(\cdot)$ is the standard normal distribution function and $\widehat{\varpi}$ are the maximum likelihood probit estimates of (2). The potential advantage of this approach compared to the self-reported response to the job insecurity question is that in being based on a continuous variable, the predicted probabilities provide more variation in

\footnotetext{
${ }^{16}$ Note that the grouping of data in bands is not necessarily a weakness of the data. For example, in the 1991 wave of the BHPS, the food consumption data were not grouped but show clear evidence of rounding (at $£ 5$ and $£ 10$ intervals). Rather than taking such data at face value, in the presence of such rounding it is preferable to treat the data as if it were grouped and to employ the GDV estimator.
} 
job insecurity levels which can be exploited to identify the relationship between consumption and job insecurity. The complication it introduces is that associated with identification.

\section{Identification}

For the model to be identified, exclusion restrictions on the consumption equation are required. This requires the isolation of at least one variable that influences income and job loss risk directly but does not affect consumption independent of the effects through income and/or risk of job loss. These exclusion restrictions are then the instruments for the respective income and job insecurity terms. This paper claims to pay special attention to this identification problem. By comparison, this issue is not discussed by Guiso et al. (1992). Moreover, inspecting their income and consumption equations indicates that no exclusion restrictions are imposed on the latter. This makes interpretation of their results difficult.

A number of alternative instrument sets will be considered below. The choice of exclusion restrictions needs to be justified on a priori grounds. On such grounds, the favoured instrument set for both income and job loss risk consists of the experience of unemployment in the previous year, the size of the household head's employer and his/her union status, although alternatives and sensitivities will be considered. The rationale for these is as follows. There is a significant body of evidence suggesting that unemployment experience has 'scarring' effects on subsequent employment and re-employment earnings (eg. Arulampalam et al. 2000, 2001). This leads us to expect significant effects from experience of unemployment in the previous year on the probability of job loss and household income. These hypotheses are confirmed in the analysis below. Since the favoured interpretation of this result is that unemployment adversely affects human capital, then there seems no reason a priori why this should be correlated with consumption behaviour independent of its effect on human capital and thereby on job insecurity and income.

A second favoured candidate for a valid instrument is that of employer (workplace) size. The earnings differential by workplace size is a key wage differential in the labour market and is quantitatively large (eg. Green et al. 1999). A favoured interpretation of this differential is one of reflecting (dynamic) monopsony associated with labour turnover costs such that larger employers bid up wage rates. There seems no reason why the resulting 
differential should be related to consumption behaviour. In terms of the risk of job loss equation, it may also be the case that jobs at larger establishments are more secure, due to larger employers possessing greater market power or that for a given employer the closure of smaller establishments incurs lower re-organisation costs. Again, it seems unlikely that this characteristic should be related to consumption independent of any effect via income or job insecurity.

Union status is also considered as a zero restriction in the consumption equations. Unions raise earnings, with this differential being associated with coverage and individual membership. Owing to the emphasis unions impose on due process they are also likely to improve job security. This leads us to expect a role for union status in both the income and job security equations. Again it seems highly unlikely that these characteristics should be related to consumption independent of the effects through household income and/or risk of job loss. A number of other candidates for valid instruments are also available and several of these are considered below. These include region, which was employed by Carroll et al. (1999) as the instrument for job loss and income in their analysis. Another possibility is being on a temporary contract which is significantly related with the probability of job loss. Nevertheless, willingness to accept a job with a temporary contract may be related to attitudes to risk which could thereby imply a relationship with consumption. Miles (1997) uses sex of the household head, education, region and occupation; their a priori justification is slightly more questionable with the strongest case for exclusion from consumption being with region of residence. In the light of this discussion, the preferred instrument set consists of past unemployment experience, employer size and union presence. ${ }^{17}$ As well as these terms, job loss risk from the probit model is also identified through the non-linear functional form of the probit model.

\footnotetext{
${ }^{17}$ Occupation is another possible instrument for job loss risk that has been used in the literature (eg. Skinner, 1988). The difficulty here is that occupational choice may be a function of attitudes to risk, rendering the resulting estimates based on excluding the occupation terms from the consumption function, inconsistent. In a similar vein, education is likely to be correlated with individuals' rates of time preference.
} 


\section{Data and Estimation Results}

\subsection{Data description}

The overwhelming majority of studies of consumption over the life-cycle and in particular the limited number of studies that investigate the precautionary motive, have been conducted using data for the United States. This paper instead employs a British data source, the British Household Panel Survey (BHPS). The BHPS consists of an annual panel-based survey of approximately 5,500 households in Britain beginning in 1991. The dataset provides detailed information on employment, education, income and demographic characteristics of households but also contains some information on consumption. The paper employs data from the BHPS for the years 1992 to $1998 .{ }^{18}$ Since the key variable of interest concerning self-reported job insecurity was only asked of respondents in waves 6 and 7 of the survey, the data employed for the specifications using self-reported job insecurity are restricted to those two cross-sections of data. The specifications that employ the estimated probability of job loss do not require this restriction.

In the BHPS, each household is asked how much (approximately) the household spends each week on food and groceries. Responses to the consumption question were banded into 12 intervals (at source), giving rise to the use of the grouped dependent variable estimator referred to in Section 3.

For self-reported unemployment expectations, in waves 6 and 7 of the survey each employed individual is asked:

"In the next twelve months, how likely do you think it is that you will become unemployed?"

Responses fall into one of four categories, 'very likely' (3.0 percent), 'likely' (6.9 percent), 'unlikely' (50.7 percent) and 'very unlikely' (39.4 percent). In view of the small proportion that respond in the 'very likely' group, for subsequent analysis this is merged with the 'likely' response thereby forming a 'likely or very likely' group.

\footnotetext{
${ }^{18}$ The survey question concerning consumption was slightly different in 1991 so this year is omitted from the analysis.
} 
The sample of households is selected on the basis of being employed, heads of household aged between 21 and 65 and providing the necessary information for each of the variables used in the analysis. This produces a sample of 10,557 heads of household available for the main analysis of household consumption functions.

\subsection{Estimation results}

Before examining the consumption functions, the models for unemployment risk are first considered. The specifications reported differ in their definition of the job insecurity termwhether this is the self-reported measure or the estimated risk of job loss.

\subsubsection{Job insecurity}

What factors are correlated with job insecurity or the perceived probability of job loss? Table 1 presents probit estimates for the propensity for individuals' self-reported job insecurity based on likely or very likely versus unlikely or very unlikely unemployment responses for 12 months hence.

The results accord with standard economic priors. Individuals on temporary or sea-

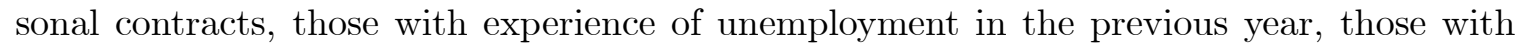
poor health, all have a higher propensity for job insecurity, controlling for the other characteristics, whilst the degree-educated have a significantly lower probability of job insecurity. By tenure, those with 1-2 years have higher levels of job insecurity than those with longer tenure. The marginal effects reported for the probit model indicate that the variables with the strongest relationship to job insecurity are being on a temporary contract, being in poor health and having experienced unemployment over the previous year. Being on a temporary contract increases the probability of feeling insecure about one's job over the subsequent year by 0.24 ; poor health increases this probability of job insecurity by 0.12 and a recent spell of unemployment by 0.10 . By comparison, having a degree qualification (relative to having no formal qualifications) is associated with a reduction in the probability of experiencing job insecurity by 0.04 .

The results for the unemployment risk models-that is of the probability of becoming unemployed in one year, from our sample of employed heads of household-are reported in Table 2. Unemployment risk is considerably higher amongst those who have previous 
experience of unemployment, controlling for other characteristics and those on temporary contracts. The marginal effect of a spell of unemployment in the previous year is an increase in the probability of becoming unemployed of 0.02 ('t-ratio'=3.98), whilst being on a temporary contract has a marginal effect of 0.033 ('t-ratio' $=5.23$ ). Given that the raw probability of entering unemployment is 0.023 , these are large effects. Larger employers tend to be associated with greater job security, although the marginal effects are non-linear. The employer size variables are jointly significant $\left(\chi^{2}(7)=25.47\right.$, p-value $\left.=0.00\right)$. Unemployment risk is significantly lower among the degree-educated, with a degree being associated with a decline in the probability of entering unemployment of 0.01 ('t-ratio' $=-2.42$ ) relative to the case of no-qualifications. Union presence in the form of union recognition but not individual union membership is also significantly and inversely related to the propensity to entering unemployment, and also has a marginal effect close to - 0.01 . Higher levels of tenure are also associated with lower unemployment risk. The pattern of results is highly plausible. Note also that the predicted probability of becoming unemployed is increasing in the self-reported job insecurity measure. The mean predicted probabilities by subjective chance of becoming unemployed are 0.0137 ("very unlikely"), 0.0153 ("unlikely") and 0.0285 ("likely or very likely").

\subsubsection{Consumption}

The main estimation results for the consumption functions are presented in Table 3. Following equation (1), household consumption is considered as a function of permanent, transitory and investment incomes, job insecurity and a set of controls.

Column 1 presents results for the specification which considers the job insecurity variable as the self-reported measure. A standard set of controls is employed, in particular through the inclusion of terms for educational attainment, number of household members in employment, family size and composition. These terms attract plausible coefficients. Household consumption is increasing in the number of children in the household and the number of employed adults.

The results in column 1 do not reject the null hypothesis $\delta=0$, that job insecurity has no influence on household consumption, contrary to the precautionary saving model. The coefficient (standard error) on the job insecurity term is -0.012 (0.024). Employing a 
slightly modified definition of self-reported job insecurity that distinguishes between three different responses in terms of the level of job insecurity does not alter this result. Although negatively signed, the results fail to indicate that job insecurity depresses consumption significantly.

As emphasised above, the limited degree of variation in the categorical variable for self-reported job insecurity may mitigate against finding a significant relation between this variable and consumption. Recall that less than 10 per cent of the sample reports that becoming unemployed is either likely or very likely. Since there will be degrees of job insecurity a case can be made for attempting to exploit such variation as a basis to the estimation. This motivates the use of the probit model for the predicted risk of becoming unemployed for our sample of employed heads of household. That there is significant variation across the sample in the predicted risk of becoming unemployment is therefore important. The coefficient of variation for this variable exceeds one (standard deviation, 0.028; mean, 0.025). The latter approach also means that the analysis is no longer restricted to the 1996 and 1997 waves of the survey that contained the self-reported job insecurity question.

Column 2 reports results for the benchmark case where zero restrictions are imposed on the unemployment experience in the previous year, employer size and union status terms. Note that these instruments are jointly significant in the income equation (reported in the Appendix) and in the unemployment risk equation (Table 2). The coefficient (standard error), multiplied by 1000, on permanent income is 0.418 (0.027) and compares to $0.112(0.017)$ on transitory income and $0.391(0.100)$ on investment income. A test of the equality of the permanent and transitory labour income coefficients easily rejects the null, $\chi^{2}(1)=85.63$ (p-value $=0.00$ ). The estimate of $\theta_{1}$ corresponds to an elasticity of food consumption with respect to permanent income of 0.18 , evaluated at mean permanent income. Recall that these estimates compare to permanent and transitory income elasticities of total consumption estimated by Miles (1997) of 0.82 and 0.61, respectively. The lower elasticities here likely reflect the fact that the measure of consumption, of necessity, is restricted to food and grocery expenditures which are likely to be less income elastic than other categories of consumption. The results generally do not suggest a different responsiveness of consumption to permanent and investment incomes.

Crucially, the unemployment risk term is now significantly negative, attracting a 
't-ratio' of -4.41 , supporting the key hypothesis associated with the precautionary saving approach. ${ }^{19}$ This is the first finding of its kind for British data. For a one standard deviation increase in unemployment risk, this estimate implies that consumption declines by 2.7 per cent. This compares to an estimate obtained by Carroll (1994) that a one standard deviation increase in predicted future income uncertainty reduces consumption by around 3 per cent, although in several of Carroll's (1994) specifications this was not statistically significant. Columns 3 to 5 consider various alternative specifications of the instrument set in order to consider the robustness of the results. These results are also favourable to the precautionary saving hypothesis that unemployment risk depresses consumption at the micro-level as well as further supporting the hypothesis that consumption responds more strongly to permanent income than to transitory income. The results also indicate a role for demographic factors associated with the size and composition of the household, consistent with results obtained by Miles (1997).

A further hypothesis considered is that theory might suggest that the effect of unemployment uncertainty should be non-linear. Thus income uncertainty, that is the variance of income associated with unemployment risk, would in principle be given by $p(1-p)(1-R)^{2} Y^{2}$, where $p$ is the predicted probability of job loss, $R$ is the replacement ratio in the event of unemployment and $Y$ is current earnings of the household head. In effect, income uncertainty should be at its peak when the probability of job loss is 0.5 since as the likelihood of job loss approaches 1 it becomes more certain that future income will be $R Y .{ }^{20}$ Since $R$ is not known, the income risk term considered in column 6 assumes it is zero, defining income risk as $\widehat{\sigma}^{2}=p(1-p) Y^{2}$ thereby attempting to pick up the notion that income at risk is greater for those with higher current earnings, ceteris paribus. This term is far from significant however such that the attempt at isolating a role for job insecurity is more successful than the attempt at constructing a proxy for income risk. The remainder of the paper focuses on the specific question of the role of job insecurity.

One possible alternative interpretation of the estmated unemployment risk effect merits discussion. The estimate of permanent income does not allow for the fact that an unem-

\footnotetext{
${ }^{19}$ The standard errors are not adjusted for the presence of a generated regressor (Pagan, 1984). As in Miles (1997), it is unlikely that this would render the key terms insignificant.

${ }^{20}$ In practice, none of the sample have a predicted probability at this level, with the maximum predicted probability of job loss over the next year in the sample being 0.371 .
} 
ployment spell will have an effect on permanent income. This point, which applies equally to previous studies, implies that the estimated unemployment risk effect could be picking up a permanent income effect. The response to this however is that the estimated job insecurity effect appears much too large to be accounted for by an implied reduction in permanent income. Taking an estimated food elasticity with respect to permanent income of 0.18 , moving from someone with zero unemployment spells to someone who spent only 2.8 per cent of their time unemployed would need to imply a reduction in permanent income of 15 per cent (ie. 0.027/0.18) to account for the estimated reduction in consumption. More plausible estimates of the likely effect on permanent income suggest that this could account for around one-fifth of the estimated effect associated with unemployment risk.

Three further experiments are now considered. The first examines whether there is any variation in the precautionary motive by age. In a precautionary saving model, it is likely that unemployment risk should have a greater effect for the young than the old. This point is made by Miles (1997, p.12), who suggests that income uncertainty is probably not independent of the number of periods lying ahead. As individuals age they accumulate liquid assets which in part act as a buffer to unemployment and their consumption should therefore be less sensitive to unemployment risk The framework of Carroll (1994, p.140) maintains that "young and middle-aged households are trying to build up a buffer stock, but by the time they have reached their peak earning years, 45-54, they have achieved a large enough buffer and so do not need to continue depressing consumption to continue building up the stock further." This hypothesis is considered here by interacting the unemployment risk term with the age of the household head. The results, also presented in Table 4, provide strong evidence in support of such an effect. The interaction term attracts a significantly positive coefficient, (with a 't-ratio' of around 4.2) indicating that the negative effect of unemployment risk upon consumption weakens with age. The estimates imply that at age 25 a one standard deviation increase in unemployment risk reduces consumption by 5.2 per cent whilst at age 60 , the effect is zero.

A second hypothesis is that individuals may respond to unemployment risk differently according to how dependent they are on earnings as a source of income. In particular, household consumption could be less sensitive to unemployment risk where households 
have other sources of income in addition to labour income. This possibility was noted by Zeldes (1989) and Miles (1997) and is considered in Table 4, through the addition of an interaction between the unemployment risk term and a dummy for whether the household reports having positive investment income-72.7 per cent of households indicate that this is the case. The results provide support for this hypothesis as the interaction term is positively signed and statistically significant. The negative impact of unemployment risk on households' consumption is muted where households possess other sources of income. For those without investment income, the one standard deviation increase in unemployment risk lowers household consumption by 4.2 per cent. Note also that the point estimate on the interaction term, at 0.969 , is less in absolute terms that the coefficient on the unemployment risk term, -1.514, suggesting that a consumption effect from unemployment risk is not removed entirely by the possession of some investment income. Given the scale of most households' investment incomes this is not surprising. ${ }^{21}$

A final possibility is to consider whether the scale of the estimated effect from unemployment risk is greater for households for whom the impact on household finances of an unemployment spell may be greater. The expected duration of any unemployment spell and the wage at which re-employment occurs will be key factors in determining this expected cost of job loss. These factors can be thought of as increasing the value of $\lambda$, that is the persistence of an income shock (such as unemployment), in section 2. As an, albeit somewhat crude, attempt to pick up any tendency for such effects, the impact of job insecurity is estimated separately for manual and non-manual employees. The economic intuition here leads us to expect that the precautionary motive should be stronger for manual workers, partly since unemployment durations are typically longer for manual workers. The coefficient (standard error) on the unemployment risk term for manual workers is -1.154 (0.301), whilst for non-manual workers it is at the margin of significance with a coefficient (standard error) of $-0.670(0.342)$. The point estimate for the unemployment risk term for manual workers implies that a one standard deviation increase in unemployment risk, reduces consumption by 3.2 per cent, whilst that for non-manual workers implies a 1.9 per cent fall in

\footnotetext{
${ }^{21}$ In a similar vein, the possibility that multiple earner households' consumption might be less sensitive to the unemployment risk of the household head was considered. No evidence for such variation was found however.
} 
consumption. Job insecurity has a stronger effect on the consumption behaviour of certain workers for whom the costs of job loss might be expected to be greater.

\section{Durables purchases}

The relation between durables expenditures and job insecurity is now considered. Indeed, it may be the case that unemployment risk is more likely to cause households to cut back or delay durables purchases than non-durables consumption, particularly food consumption, the case considered above. As noted above, the model of Carroll and Dunn (1997) of consumer durables purchases has this key implication, that greater labour income uncertainty delays the purchase of durables, as it is optimal for households to add further to their precautionary assets. Carroll and Dunn (1997) examine aggregate data on durables purchases and unemployment expectations in the US and their results lend support to this implication. They recommend however, that a household-level probit model be run regressing durables purchases on job insecurity data.

Data on durables expenditures at the micro-level are limited but available data from the BHPS justify such an exercise. The BHPS includes information on whether the household has purchased nine listed consumer durables in the past year. ${ }^{22}$ The procedure employed here is to consider the propensity for a household to have purchased any of these consumer durables in the previous year as a function of the job insecurity of the household head, according to both the self-reported and estimated unemployment risk, and the full set of household- and individual-level controls. This is estimated as a probit model with the results presented in Table 4 .

The probability of having recently purchased consumer durables for the household varies inversely with job insecurity. This provides empirical support for the notion that unemployment risk delays consumer durables purchases. Employing the model-based predicted risk of unemployment, the term is on the margin of significance. For the durables purchase probits, the results using the self-reported measure of job insecurity indicate a stronger role for unemployment expectations, as the term attracts a coefficient (standard error) of $-0.182(0.081)$. The marginal effect implies that reporting some level of job inse-

\footnotetext{
${ }^{22}$ The consumer durables are the following: colour TV, VCR, freezer, washing machine, tumble dryer, dish washer, microwave, home computer and CD player. The proportion of households that undertake any such purchase in the previous year is 0.465 .
} 
curity is associated with a 0.07 lower probability of having recently purchased a consumer durable. Relative to an overall proportion of households that report any consumer durable purchase in the past year of 0.465 , this is by no means a small effect.

\section{Conclusions}

This paper has confronted several implications of the precautionary model of consumption/saving with micro data on British households for the first time. By relating consumption to job insecurity, controlling for other characteristics including estimated permanent income, evidence in favour of a precautionary motive for saving associated with unemployment risk has been found. The analysis can also be considered an attempt to examine some of the effects of job insecurity, a phenomenon which has attracted significant interest in Britain (eg. Nickell et al. 2002). Despite the large literature that has developed assessing job insecurity in the British labour market, there has been little if any attempt to consider how job insecurity might affect household decision-making. This paper has considered household consumption as a potential such case, at the same time assessing the empirical merit of a central implication of the precautionary model of saving.

As a test of the precautionary model of saving the approach adopted here, through the use of estimated and self-reported unemployment risk, is preferable over other attempts that have attempted to define income uncertainty on the basis of the variability in income over a (very) limited number of years or through an additional non-linearity in the relationship between consumption and income. Unemployment risk is likely to represent the dominant form of income uncertainty to households of working age, is less likely to be due to voluntary (and anticipated) changes in behaviour and can arguably be more reliably measured than previous measures of income risk.

The results have been broadly favourable to the key implication of precautionary saving, namely that greater unemployment risk should depress levels of household consumption. This result was found in the models that constructed a predicted probability of becoming unemployed for a sample of employed heads of household. Across the sample as a whole, the estimates implied that a one standard deviation increase in unemployment risk lowers household (food) consumption by 2.7 per cent. This represents an appreciable impact. It 
was also found that the unemployment risk effect is stronger for the young as implied by a buffer-stock model of saving such as Carroll (1994) where individuals accumulate assets earlier in their working life as a precautionary buffer to income shocks. At age 25, a one standard deviation increase in unemployment risk is estimated to reduce consumption by 5.2 per cent whilst by age 60 , the effect is zero. Those that are more reliant upon labour income, that is do not have investment income are also found to be more sensitive in terms of their consumption to unemployment risk as we would expect. For those without investment income, the one standard deviation increase in unemployment risk lowers household consumption by 4.2 per cent. Further, variation by occupational group was also considered. The consumption of manual workers, for whom the persistence of a shock to income induced by unemployment is likely to be greater given typically longer unemployment durations, were found to be more sensitive to job insecurity.

The paper has also explored the relation between consumer durables purchases and job insecurity. In so doing the analysis has responded to Carroll and Dunn's (1997) concluding recommendation for future research. The probability of the household having recently purchased consumer durables varied inversely with job insecurity of the household head. This provides empirical support for the notion that unemployment risk causes households to delay consumer durables purchases as in the model of Carroll and Dunn (1997). In this model, an increase in labour income uncertainty such as that originating from greater job insecurity leads households to delay purchase of consumer durables as households instead opt to add to their precautionary assets which are used as a buffer against the higher level of uncertainty. In the estimates presented here, use of the self-reported measure of job insecurity implied that some degree of job insecurity was associated with a reduction in the probability of having recently purchased a consumer durable of 0.07 -by no means a small effect.

For the UK, the most persuasive prior evidence of precautionary saving is that of Banks et al. (2001), who adopt an approach based on the construction of a cohort-defined quasi-panel, which distinguishes between cohort-specific and common income risks. Their results find strong evidence of precautionary saving, in particular associated with the cohortspecific income risk component. This paper has instead focused specifically on unemployment risk as a potentially major source of disruption to income and in order to consider the 
possible effects of job insecurity. Banks et al. (2001) suggest that income uncertainty was increasing through much of the 1980s and early 1990s in the UK. Unemployment risk, at least since the early 1990s, has likely been falling. This may point to other sources of income risk as increasing in importance. Future research might therefore consider these other forms of income uncertainty, such as wage flexibility, which may have increased in importance in the British labour market, as well as in Spain, in giving rise to a precautionary motive for saving. 
Table 1: Self-reported Job Insecurity

\begin{tabular}{|c|c|c|}
\hline & coefficient (standard error) & "marginal effect \\
\hline \multicolumn{3}{|l|}{ Education (highest qualification) } \\
\hline Degree & $-0.292(0.132)$ & -0.038 \\
\hline Other Higher QF & $-0.170(0.102)$ & -0.024 \\
\hline A-levels & $-0.087(0.119)$ & -0.012 \\
\hline O-levels or equivalent & $-0.176(0.105)$ & -0.024 \\
\hline CSEs, commercial QF or other & $0.008(0.121)$ & 0.001 \\
\hline unemployed in previous year & $0.467(0.123)$ & 0.099 \\
\hline temporary contract & $0.977(0.108)$ & 0.244 \\
\hline aged 30 to 39 & $0.181(0.104)$ & 0.028 \\
\hline aged 40 to 49 & $0.410(0.102)$ & 0.070 \\
\hline aged 50 or more & $0.449(0.107)$ & 0.080 \\
\hline poor health & $0.581(0.115)$ & 0.122 \\
\hline covered union member & $0.065(0.073)$ & 0.010 \\
\hline covered non-union member & $0.054(0.084)$ & 0.008 \\
\hline married & $-0.027(0.092)$ & -0.004 \\
\hline white & $-0.279(0.156)$ & -0.050 \\
\hline male & $-0.008(0.091)$ & -0.001 \\
\hline tenure: $7-12$ months & $0.062(0.117)$ & 0.010 \\
\hline tenure: $1-2$ years & $0.217(0.105)$ & 0.036 \\
\hline tenure: $2-4$ years & $0.206(0.103)$ & 0.033 \\
\hline $\begin{array}{l}\text { tenure: } 4 \text { years or more } \\
\text { workplace size: }\end{array}$ & $0.046(0.096)$ & 0.007 \\
\hline 10 to 24 employees & $-0.118(0.108)$ & -0.016 \\
\hline 25 to 49 employees & $0.007(0.107)$ & 0.001 \\
\hline 50 to 99 employees & $-0.146(0.115)$ & -0.020 \\
\hline 100 to 199 employees & $-0.033(0.113)$ & -0.005 \\
\hline 200 to 499 employees & $0.043(0.102)$ & 0.007 \\
\hline 500 to 999 employees & $-0.167(0.132)$ & -0.023 \\
\hline 1000 or more employees & $-0.125(0.114)$ & -0.017 \\
\hline occupation dummies & yes $(8)$ & \\
\hline region dummies & yes (18) & \\
\hline wave dummy & yes & \\
\hline log-likelihood & -1211.229 & \\
\hline pseudo R-squared & 0.098 & \\
\hline observations & 4,211 & \\
\hline
\end{tabular}

Note: Table reports maximum likelihood probit estimates for self-reported job insecurity. Standard errors corrected for multiple observations in parentheses. The reference groups are no qualifications; aged 21-29; 1-6 months' tenure with a workplace size of 1-9 employees; Other higher QF refers to teaching, nursing or other higher qualifications. 
Table 2: Unemployment Risk

\begin{tabular}{|c|c|c|}
\hline & 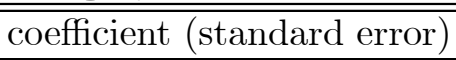 & marginal effect \\
\hline \multicolumn{3}{|l|}{ Education (highest qualification) } \\
\hline Degree & $-0.292(0.121)$ & -0.009 \\
\hline Other Higher QF & $-0.129(0.086)$ & -0.005 \\
\hline A-levels & $0.096(0.095)$ & 0.004 \\
\hline O-levels or equivalent & $-0.043(0.086)$ & -0.002 \\
\hline CSEs, commercial QF or other & $0.015(0.097)$ & 0.001 \\
\hline unemployed in previous year & $0.380(0.095)$ & 0.022 \\
\hline temporary contract & $0.503(0.096)$ & 0.033 \\
\hline covered union member & $-0.198(0.062)$ & -0.007 \\
\hline covered non-union member & $-0.288(0.082)$ & -0.009 \\
\hline aged 30 to 39 & $-0.022(0.076)$ & -0.001 \\
\hline aged 40 to 49 & $0.076(0.080)$ & 0.003 \\
\hline aged 50 or more & $0.224(0.086)$ & 0.010 \\
\hline poor health & $0.218(0.115)$ & 0.011 \\
\hline married & $-0.194(0.080)$ & -0.009 \\
\hline white & $-0.170(0.132)$ & -0.008 \\
\hline male & $0.092(0.079)$ & 0.003 \\
\hline \multicolumn{3}{|l|}{ tenure: } \\
\hline 7-12 months & $0.001(0.091)$ & 0.000 \\
\hline $1-2$ years & $-0.081(0.092)$ & -0.003 \\
\hline $2-4$ years & $-0.103(0.088)$ & -0.004 \\
\hline 4 years or more & $-0.277(0.082)$ & -0.011 \\
\hline \multicolumn{3}{|l|}{ workplace size: } \\
\hline 10 to 24 employees & $-0.258(0.086)$ & -0.008 \\
\hline 25 to 49 employees & $-0.178(0.090)$ & -0.006 \\
\hline 50 to 99 employees & $-0.239(0.099)$ & -0.008 \\
\hline 100 to 199 employees & $-0.034(0.088)$ & -0.001 \\
\hline 200 to 499 employees & $-0.377(0.092)$ & -0.012 \\
\hline 500 to 999 employees & $-0.284(0.115)$ & -0.009 \\
\hline 1000 or more employees & $-0.250(0.110)$ & -0.008 \\
\hline occupation dummies & yes $(8)$ & \\
\hline region dummies & yes (17) & \\
\hline wave dummies & yes $(6)$ & \\
\hline log-likelihood & -1320.979 & \\
\hline pseudo R-squared & 0.098 & \\
\hline observations & 13,288 & \\
\hline
\end{tabular}

Notes: Table reports maximum likelihood probit estimates for risk of job loss. Standard errors in parentheses. 
Table 3: Consumption

\begin{tabular}{|c|c|c|c|c|c|c|}
\hline & Self-reported job insecurity & \multicolumn{5}{|c|}{ Estimated unemployment risk } \\
\hline & {$[1]$} & {$[2]$} & {$[3]$} & {$[4]$} & {$[5]$} & {$[6]$} \\
\hline permanent income, $y^{P}$ & $0.410(0.049)$ & $0.418(0.027)$ & $0.413(0.027)$ & $0.448(0.026)$ & $0.418(0.027)$ & $0.434(0.027)$ \\
\hline transitory income, $y^{T}$ & $0.120(0.033)$ & $0.112(0.017)$ & $0.113(0.017)$ & $0.114(0.017)$ & $0.112(0.017)$ & $0.113(0.018)$ \\
\hline investment income, $y^{W}$ & $0.443(0.158)$ & $0.391(0.100)$ & $0.404(0.101)$ & $0.390(0.101)$ & $0.392(0.100)$ & $0.406(0.099)$ \\
\hline job insecurity, $\widehat{u}$ & $-0.012(0.024)$ & $-0.982(0.223)$ & $-0.723(0.246)$ & $-0.641(0.228)$ & $-0.901(0.194)$ & \\
\hline income risk, $\widehat{\sigma}^{2}$ & & & & & & $0.313(0.955)$ \\
\hline Household & & & & & & \\
\hline married & $0.305(0.022)$ & $0.306(0.012)$ & $0.309(0.012)$ & $0.297(0.012)$ & $0.307(0.012)$ & $0.311(0.012)$ \\
\hline number of children & $0.197(0.008)$ & $0.202(0.005)$ & $0.201(0.005)$ & $0.200(0.005)$ & $0.201(0.005)$ & $0.198(0.004)$ \\
\hline number of employed adults & $0.118(0.013)$ & $0.114(0.007)$ & $0.115(0.007)$ & $0.113(0.007)$ & $0.115(0.007)$ & $0.116(0.007)$ \\
\hline Tes: $\theta_{1}=\theta_{2} ; \chi^{2}(1)$ & $21.75(\mathrm{p}=0.000)$ & $85.63(\mathrm{p}=0.000)$ & $82.21(\mathrm{p}=0.000)$ & $104.85(\mathrm{p}=0.000)$ & $85.52(\mathrm{p}=0.000)$ & $96.35(\mathrm{p}=0.000)$ \\
\hline Test: $\theta_{1}=\theta_{3} ; \chi^{2}(1)$ & $0.04(\mathrm{p}=0.848)$ & $0.07(\mathrm{p}=0.799)$ & $0.01(\mathrm{p}=0.928)$ & $0.29(\mathrm{p}=0.592)$ & $0.06(\mathrm{p}=0.811)$ & $0.07(\mathrm{p}=0.786)$ \\
\hline log-likelihood & -6041.816 & -19583.972 & -19580.175 & -19628.476 & -19584.253 & -20638.352 \\
\hline s.e. & $0.373(0.005)$ & $0.370(0.003)$ & $0.369(0.003)$ & $0.371(0.003)$ & $0.370(0.003)$ & $0.372(0.003)$ \\
\hline observations & 3,204 & 10,557 & 10,557 & 10,557 & 10,557 & 10,557 \\
\hline
\end{tabular}

Notes: Table reports maximum likelihood estimates for grouped dependent variable model (Stewart, 1983). Dependent variable is $\log$ household consumption on food and groceries (weekly). Standard errors in parentheses. Coefficients and standard errors on $y^{P}, y^{T}$ and $y^{W}$ multiplied by 1000 . s.e. is the standard error of the regression. $\theta_{1}=\theta_{2}\left(\theta_{3}\right)$ is a $\chi^{2}(1)$ test of the hypothesis that the permanent and transitory (investment) income coefficients are equal. Other controls included are age dummies (3), education (5), male, poor health, white, tenure (4), occupation (8) and year (6).
Instrument sets:
[1] unemployed previous year, employer size, union status.
[2] unemployed previous year, employer size, union status.
[3] unemployed previous year, employer size.
[4] unemployed previous year, employer size, and region.
[5] unemployed previous year, employer size, union and temporary contract.
[6] unemployed previous year, employer size, union status. 
Table 4: Further Experiments

\begin{tabular}{|c|c|c|c|c|c|c|}
\hline & \multicolumn{4}{|c|}{ Consumption } & \multicolumn{2}{|c|}{$\operatorname{Pr}$ (any durables purchase in previous year) } \\
\hline & Age interaction & Investment income & Manual & Non-manual & Self-reported $\widehat{u}$ & Model-based $\widehat{u}$ \\
\hline permanent income, $y^{P}$ & $0.420(0.026)$ & $0.413(0.027)$ & $0.479(0.051)$ & $0.410(0.030)$ & $0.226(0.164)$ & $0.289(0.085)$ \\
\hline transitory income, $y^{T}$ & $0.112(0.017)$ & $0.112(0.017)$ & $0.390(0.050)$ & $0.083(0.019)$ & $0.292(0.124)$ & $0.110(0.054)$ \\
\hline investment income, $y^{W}$ & $0.385(0.100)$ & $0.355(0.101)$ & $0.038(0.278)$ & $0.442(0.110)$ & $-0.406(0.546)$ & $-0.000(0.321)$ \\
\hline job insecurity, $\widehat{u}$ & $-3.243(0.586)$ & $-1.514(0.257)$ & $-1.154(0.301)$ & $-0.670(0.342)$ & $-0.182(0.081)$ & $-1.333(0.687)$ \\
\hline job insecurity $\mathrm{X}$ age & $0.055(0.013)$ & & & & & \\
\hline job insecurity $\mathrm{X}\left(y^{W}>0\right)$ & & $0.969(0.234)$ & & & & \\
\hline Test: $\theta_{1}=\theta_{2} ; \chi^{2}(1)$ & $87.35(\mathrm{p}=0.000)$ & $83.20(\mathrm{p}=0.000)$ & $1.56(\mathrm{p}=0.212)$ & $69.97(\mathrm{p}=0.00)$ & $0.09(\mathrm{p}=0.762)$ & $2.89(\mathrm{p}=0.090)$ \\
\hline Test: $\theta_{1}=\theta_{3} ; \chi^{2}(1)$ & $0.11(\mathrm{p}=0.744)$ & $0.30(\mathrm{p}=0.586)$ & $2.34(\mathrm{p}=0.126)$ & $0.07(\mathrm{p}=0.788)$ & $1.15(\mathrm{p}=0.283)$ & $0.76(\mathrm{p}=0.384)$ \\
\hline log-likelihood & -19575.271 & -19575.43 & -7772.664 & -11725.44 & -2116.443 & -7939.840 \\
\hline s.e. & $0.369(0.003)$ & $0.369(0.003)$ & $0.347(0.004)$ & $0.381(0.004)$ & - & - \\
\hline observations & 10,557 & 10,557 & 4,297 & 6,260 & 3,203 & 11,775 \\
\hline
\end{tabular}

Notes: Consumption equations are maximum likelihood estimates as in Table 3. See notes to Table 3. All consumption equations use predicted unemployment risk as the measure of job insecurity. Instruments are unemployed previous year, employer size dummies and union status.

Any durables purchase refers to the purchase of consumer durables in the previous year, estimated as a probit model. 


\section{Data Appendix}

The data are derived from the British Household Panel Survey, obtained through the Data Archive at the University of Essex. Full details of the survey design are available from Taylor et al. (1999). This Data Appendix describes the construction of the some of the key variables and provides summary statistics. Labels referred to in square parentheses [.] below are the original BHPS variable names (where 'W' varies according to the wave of the survey).

\section{Variable Construction}

\section{Consumption}

The 12-way categorical response is derived from household-level responses to the following question, "Tell me approximately how much your household spends each week on food and groceries?" [Wxpfood]

\section{Current income}

Household income in month prior to survey [Wfihhmn]. Imputed values [Wfihhmni=1] on this variable are omitted from the analysis. Converted to weekly equivalent values and deflated using the GDP deflator.

\section{Permanent Income}

The construction of the measure of permanent income takes as its starting point a regression for current household labour income on observable characteristics, $Z_{i t}$. Defining the age- and cohort-effects as $\pi(\alpha)_{i}$ and $\phi(c)_{i}$, respectively gives the following cross-sectional equation for log current household income, $y_{i t}$ :

$$
y_{i t}=Z_{i t} \varphi+\pi(\alpha)_{i}+\phi(c)_{i}+v_{i t}
$$

The cohort effects $\phi(c)_{i}$ cannot be separately identified from the age effects $\pi(\alpha)_{i}$ in cross-sectional data. External estimates of the age effects from Benito (2001) are therefore employed to produce cohort-adjusted estimates of the age effects on current household income, $\widehat{\pi}(\alpha)_{i}$. The error term, $v_{i t}$ in (3) consists of an unobserved (permanent) heterogeneity component, $v_{i}$ and transitory income component, $\epsilon_{i t}$

$$
v_{i t}=v_{i}+\epsilon_{i t} .
$$

The income equation (3) is therefore estimated as a random effects model allowing for the unobserved heterogeneity through the random effects error component, $v_{i}$. As in Guiso et al. (1992), under the assumption that the interest rate equals the rate of productivity growth, permanent labour income is then calculated as

$$
y_{i t}^{P}=\left(T^{R}-\alpha_{i}\right)^{-1} \sum_{\alpha=\alpha_{i}}^{T^{R}}\left(Z_{i t} \widehat{\varphi}+\widehat{\pi}(\alpha)_{i}+v_{i}\right)
$$

where $T^{R}$ is retirement age (assumed 65 for men and 60 for women) and $\alpha$ is current age. 


\section{Transitory Income}

Transitory income is defined as the difference between current and permanent income.

\section{Investment income}

Amount received in the form of dividends or interest from any savings and investments.

\section{Job insecurity}

Two approaches to job insecurity are employed. The first considers a self-reported measure derived from head of household responses to the question, "In the next twelve months, how likely do you think it is that you will become unemployed?" [Weprosc]

The second approach estimates probit models for the probability of becoming unemployed, as described in the text.

\section{Demographics}

The additional variables included in the analysis are indicators for a range of demographic characteristics. Summary statistics for these and the variables described above are reported in Table A.1. 
Table A.1: Summary statistics

\begin{tabular}{l|c}
\hline \hline \multicolumn{1}{c|}{ Variable } & \\
\hline current income & $499.77(319.66)$ \\
permanent income & $438.74(209.59)$ \\
transitory income & $62.15(217.73)$ \\
investment income & $12.26(38.13)$ \\
estimated unemployment risk & $0.025(0.028)$ \\
self-reported job insecurity (binary coding) & 0.095 \\
Education (highest qualification) & \\
Degree & 0.164 \\
Other Higher QF & 0.267 \\
A-levels & 0.129 \\
O-levels or equivalent & 0.197 \\
CSEs, commercial QF or other & 0.085 \\
unemployed in previous year & 0.045 \\
temporary contract & 0.040 \\
covered union member & 0.395 \\
covered non-union member & 0.153 \\
aged 30 to 39 & 0.335 \\
aged 40 to 49 & 0.287 \\
aged 50 or more & 0.195 \\
poor health & 0.037 \\
married & 0.744 \\
white & 0.966 \\
male & 0.807 \\
number of children & $0.706(0.986)$ \\
number of employed adults in household & $1.788(0.733)$ \\
tenure: 1-6 months & 0.148 \\
tenure: 7-12 months & 0.091 \\
tenure: 1-2 years & 0.134 \\
tenure: 2-4 years & 0.191 \\
tenure: 4 years or more & 0.436 \\
workplace size: & \\
10 to 24 employees & 0.133 \\
50 to 49 employees 99 employees & 0.124 \\
100 to 199 employees & 0.129 \\
500 to 499 employees & 0.118 \\
1000 or more employees & 0.166 \\
\hline \hline & 0.084 \\
\hline
\end{tabular}

Note: Table reports sample means (standard deviations in parentheses, where applicable) for sample used in the unemployment risk regression $(\mathrm{n}=13,288)$. 
Table A.2: Household labour income

\begin{tabular}{l|c}
\hline \hline & log current household income \\
\hline Education (highest qualification) & $0.443(0.021)$ \\
Degree & $0.216(0.017)$ \\
Other Higher QF & $0.191(0.020)$ \\
A-levels & $0.146(0.018)$ \\
O-levels or equivalent & $0.066(0.023)$ \\
CSEs, commercial QF or other & $-0.087(0.014)$ \\
unemployed in previous year & $-0.065(0.015)$ \\
temporary contract & $0.088(0.009)$ \\
covered union member & $0.016(0.010)$ \\
covered non-union member & $-0.018(0.014)$ \\
poor health & $0.272(0.011)$ \\
married & $0.101(0.033)$ \\
white & $0.192(0.016)$ \\
male & $-0.031(0.004)$ \\
number of children & $0.281(0.005)$ \\
number of employed adults & \\
tenure: & $0.006(0.009)$ \\
7-12 months & $-0.001(0.008)$ \\
2-2 years & $0.011(0.008)$ \\
4 years & $0.016(0.008)$ \\
workplace size: & \\
10 to 24 employees & \\
25 to 49 employees & $0.030(0.011)$ \\
100 to 199 employees & $0.049(0.012)$ \\
200 to 499 employees & $0.076(0.012)$ \\
1000 or more employees & $0.081(0.012)$ \\
occupation dummies & $0.080(0.011)$ \\
region dummies & $0.107(0.013)$ \\
wave dummies & $0.103(0.013)$ \\
& yes $(8)$ \\
observations & yes $(18)$ \\
\hline \hline & \\
\hline
\end{tabular}

Note: Table reports maximum likelihood estimates of a random effects model. $\rho$ represents the proportion of the total variance accounted for by the panel individual-specific component. Standard errors in parentheses. 


\title{
Annex: Dissaving, Income Expectations and Job Insecurity
}

\author{
I. INTRODUCTION
}

Do people save for a rainy day? This implication of the permanent income model is highlighted by Campbell (1987) and confronted with quarterly data for the U.S. High levels of saving are found to precede slower than average growth in (labor) income, supporting the key hypothesis. However, Campbell (p.1272) concluded that "An important task for future research is to apply the methods of this paper... to disaggregated data sets".

Carroll (1992) also considers Campbell's (1987) saving for a rainy day hypothesis but uses survey data concerning attitudes to drawing down saving and to borrowing as well as income and unemployment expectations. However, Carroll's (1992) analysis is also conducted at the aggregate level. A further motivation for Carroll's (1992) study is to examine the implication under a precautionary saving model that unemployment expectations affect intentions to save controlling for expectations regarding income.

In this Annex I use individual-level survey responses to questions identical to those employed by Carroll (1992) that were present in the British Household Panel Survey (BHPS) in the period 1993-1995. This provides the basis to the microeconomic consideration of Campbell's (1987) hypothesis above with the further contribution being to consider whether households' attitudes to dissaving and/or borrowing are influenced by their level of job insecurity as considered by Carroll (1992) but by employing disaggregated data.

\section{The Data}

The British Household Panel Survey (BHPS) is an individual- and household-level survey carried out annually in Britain since $1991 .{ }^{23}$ The data provide detailed labour market, education and demographic information and the 1993 to 1995 waves of the survey contain information on the attitudes of individuals to running down their savings and to taking on additional debt as well as their (qualitative) expectations for their financial situations over the next year. Specifically, in order to examine attitudes to dissaving and debt, responses to the following questions are employed.

\section{Dissaving}

The willingness of the household head to dissave is considered as the response 'all right' to the following question. "If there were a major purchase that you wanted to make, do you think that now is a time when it would be all right to use some of your savings, or is now a time when you would be especially reluctant to use some of your savings?"

As in Carroll (1992) a reasonable assumption is that those individuals that are more willing to dissave are relatively less keen to save and vice versa.

Attitude to credit

\footnotetext{
${ }^{23}$ That is, each adult member in a representative sample of around 5,500 households in Britain in 1991 was interviewed. These Original Sample Members are then re-interviewed at subsequent waves, as are other adults with whom they form new households.
} 
Willingness to use credit is considered as the response 'all right' to the following question. "If there were something big that you wanted to buy, do you think that now is a time when it would be all right for you personally to buy on credit, or is now a time when you would be especially reluctant to take on a new debt?"

\section{Financial expectations}

Positive financial expectations are defined as the response 'better than now' to the question. "Looking ahead, how do you think you will be financially a year from now?" Negative financial expectations will be considered as a dummy for the response "worse than now'. Saving for a rainy day implies that willingness to dissave is a negative function of adverse income expectations.

These three questions are identical to those used by Carroll (1992), from the University of Michigan Surveys of Consumers. Carroll (1992) regressed the proportion of households in each month that responded that they were especially reluctant to dissave less the proportion stating it would be 'OK' to dissave on the proportion reporting they expect their household income to increase less the proportion expecting it to fall and a measure of unemployment expectations. The latter consisted of the proportion of respondents expecting unemployment to rise less the proportion expecting it to fall. It was found that reluctance to dissave was positively related to adverse income expectations, though this effect was generally less robust than that associated with expectations regarding unemployment. This led to the conclusion that there was some evidence of individuals saving for a rainy day in terms of their income expectations but stronger evidence for the role of job insecurity consistent with a precautionary motive. ${ }^{24}$

The contribution of the present analysis is to conduct a similar analysis at the individual-level. This is important for the following reasons. First, at the aggregate level issues of endogeneity are likely to be much more severe. Additional saving in response to some other shock, may increase unemployment and unemployment expectations as aggregate demand declines. Such effects are clearly less problematic in corrupting micro-based estimates. Second, both of the key variables, short-term income expectations and job insecurity may be correlated with permanent income. In the present analysis a permanent income variable can be constructed and added to control for this effect. More generally, there are likely to be substantial benefits in carrying out this exercise using micro-data and exploiting variation between households, whilst essentially holding the state of the aggregate economy constant. Third, Zeldes (1992, p.146-9) discusses a number of other problems in using responses to these questions, when aggregated across households. For example, Zeldes (1992) argues that Carroll's (1992) use of the proportion of households expecting unemployment to rise less the proportion expecting unemployment to fall over the year is a measure of the concensus regarding future unemployment rather than unemployment risk per se. This is avoided in using the individual-level responses.

The sample is selected on being employed, heads of household of working age, whilst providing relevant information for the construction of each on the variables used in the analysis in at least two years of the survey.

\footnotetext{
${ }^{24}$ Kuehlwain (1991) provides an example of a micro-based study of precautionary saving based on an attempt to estimate an Euler equation. The results are relatively unfavourable to the precautionary saving approach.
} 


\section{Estimation AND RESULTS}

Random effects probit models are estimated, represented by the following.

$$
\text { dissave }_{i t}=1\left\{\alpha_{i}+\beta_{1} y_{i t}^{e-}+\beta_{2} y_{i t}^{e+}+\gamma \widehat{u}_{i t}+X_{i t}^{\prime} \theta+\varepsilon_{i t}>0\right\}
$$

where $i$ indexes individual heads of household $i=1,2 . . N$ and $t$ indexes years $t=1993$, 1994, 1995. $1\{A\}$ is an indicator function for the event $A$, where this reflects being 'all right' to dissave. $\alpha_{i}$ denotes an unobserved individual-specific component that is assumed random across individuals with $\alpha_{i} \sim N\left(0, s_{\alpha}^{2}\right) . \varepsilon_{i t} \sim\left(0, s_{\varepsilon}^{2}\right)$ represents random error and is assumed to be independent of $\alpha_{i}$. $\alpha_{i}$ and $\varepsilon_{i t}$ are also assumed orthogonal to the set of covariates, which consist of the indicators for negative expectations over the following year $\left(y^{e-}\right)$ positive expectations $\left(y^{e+}\right)$, job insecurity $(\widehat{u}$, defined below) and the set of controls $X$, which includes a set of individual and household demographic variables including an estimate of permanent income with associated parameter vector $\theta$. Estimation is by maximum likelihood. ${ }^{25}$

The canonical permanent income model asserts that $\beta_{1}<0$, and $\beta_{2}>0$, where both coefficients are relative to the base group of the person's financial situation being 'about the same' over the next year. ${ }^{26}$ The precautionary saving model adds to this hypothesis that $\gamma<0$. Even controlling for income expectations, job insecurity has an independent effect, which it does not have in the permanent income model. As in Carroll (1992) it is also of interest to look at individuals' attitudes to credit and how these are influenced by income expectations and job insecurity. I therefore repeat the analysis above considering an indicator for 'all right' to borrow as the relevant measure of attitudes to credit.

Two further measurement issues arise: first concerning job insecurity and second concerning permanent income. A model is constructed for the probability that the employed head of household becomes unemployed the following year. This is estimated as a standard probit model for the heads of household. Using the derived maximum likelihood estimates, predicted probabilities of job loss are then constructed for each head of household in the sample. Since this is likely to be measured with error, the job insecurity measure is instrumented using the previous experience of unemployment and employer size as instruments for job insecurity. These terms are highly correlated with the propensity to become unemployed.

For permanent income, this is estimated as an age- and cohort-adjusted present value of future income, derived from a random effects panel regression for log household income (see also Guiso et al. 1992). The same instruments as for job insecurity are used, namely the experience of unemployment in the previous year and employer size. Again these terms are highly significant in the log household income equation and, independent of any effect operating via income and job insecurity should not be expected to be related to consumption/saving.

Estimation results are presented in Table 1. The key results are the following. First, the willingness of an individual to dissave is significantly lower for those who believe they

\footnotetext{
${ }^{25}$ See STATA manual (StataCorp, 2001) for the likelihood function.

${ }^{26}$ The sample proportions of individuals reporting 'better than now', 'worse than now' and 'about the same' financial expectations are $31.7 \%, 14.9 \%$ and $53.4 \%$, respectively.
} 
will be worse off in a year's time. This is consistent with the key hypothesis of saving for a rainy day. The 'worse than now' income expectations dummy attracts a coefficient (standard error) of -0.333 (0.086), relative to the base group of income expectations 'about the same'. Second, willingness to dissave is inversely related to unemployment risk, with the job insecurity coefficient (standard error) estimated at -6.635 (2.463). The marginal effect associated with this estimate implies that a one standard deviation $\left(s_{u}=0.028\right)$ increase in unemployment risk, reduces the probability of being willing to dissave by $-0.048 .{ }^{27}$ Relative to a proportion of those willing to dissave of 0.301 , this is an appreciable effect. This unemployment risk effect on willingness to (dis)save is inconsistent with the canonical (certainty equivalent) permanent income model but is consistent with the implication of a precautionary saving model where labour income uncertainty is important. ${ }^{28}$

Results for willingness to use credit are qualitatively similar to those described above for dissaving. Finally, results are presented for willingness to either dissave or use credit. This is found to be significant lower for households with adverse expectations for their financial position over the next year and significantly lower for those at greater risk of losing their jobs.

\section{CONCLuSion}

This Annex has examined saving, income expectations and job insecurity and provides a micro-data based treatment of the aggregate studies by Campbell (1987) of the relation between saving and income expectations and by Carroll (1992) who considers buffer-stock saving in response to job insecurity. Using individual-level survey responses from the British Household Panel Survey (BHPS), for questions identical to those studied by Carroll (1992) at an aggregate level for the U.S., the analysis finds evidence of an individual's willingness to save increasing when s/he expects his or her financial situation to deteriorate over the next year-ie.'saving for a rainy day'-with a further effect from job insecurity as measured by the risk of job loss. These results are consistent with a forward-looking life-cycle/permanent income model of saving supplemented by a precautionary motive for saving.

\footnotetext{
${ }^{27}$ This marginal effect is calculated using the formula presented by Arulampalam (1999) for the random effects probit model.

${ }^{28}$ The one counterintuitive aspect of the estimation results is that the term for improved financial expectations over the next year is also negatively signed, suggesting that individuals are also less willing to dissave when income expectations are positive. The point estimate on this term is, however, smaller than that on income expectations 'worse than now'. Moreover, a test of the hypothesis that the coefficients on the better than now and worse than now financial expectations are equal is rejected at the 5 per cent level. $\left(\chi^{2}(1)=3.88\right.$, p-value=0.049). When the permanent income control is added to the specification for dissaving the counter-intuitive result for improved financial expectations, becomes insignificant.
} 
Table 1: Estimation results

\begin{tabular}{|c|c|c|c|c|c|c|}
\hline & \multicolumn{2}{|c|}{ Dissaving } & \multicolumn{2}{|c|}{ Credit } & \multicolumn{2}{|c|}{ Dissaving or credit } \\
\hline $\begin{array}{l}\text { Financial expectations } \\
\text { worse than now } \\
\text { better than now } \\
\text { Unemployment risk } \\
\text { Permanent income* }\end{array}$ & $\begin{array}{l}-0.333(0.086) \\
-0.142(0.069) \\
-6.635(2.463)\end{array}$ & $\begin{array}{c}-0.304(0.090) \\
-0.128(0.072) \\
-5.693(2.507) \\
0.140(0.025)\end{array}$ & $\begin{array}{l}-0.317(0.090) \\
-0.033(0.069) \\
-5.355(2.675)\end{array}$ & $\begin{array}{c}-0.301(0.094) \\
-0.022(0.072) \\
-3.562(2.719) \\
0.079(0.025)\end{array}$ & $\begin{array}{l}-0.314(0.079) \\
-0.097(0.063) \\
-5.490(2.189)\end{array}$ & $\begin{array}{c}-0.283(0.082) \\
-0.100(0.066) \\
-3.924(2.227) \\
0.120(0.024)\end{array}$ \\
\hline $\begin{array}{l}\text { log-likelihood } \\
\rho \\
\text { observations }\end{array}$ & $\begin{array}{c}-2,154.57 \\
0.454(0.030) \\
3,840\end{array}$ & $\begin{array}{c}-1,990.85 \\
0.451(0.032) \\
3,572\end{array}$ & $\begin{array}{c}-1,946.37 \\
0.404(0.033) \\
3,854\end{array}$ & $\begin{array}{c}-1,805.32 \\
0.409(0.035) \\
3,581\end{array}$ & $\begin{array}{c}-2,398.71 \\
0.389(0.029) \\
3,835\end{array}$ & $\begin{array}{c}-2,219.61 \\
0.388(0.031) \\
3,565\end{array}$ \\
\hline
\end{tabular}

Notes: Maximum likelihood random effects probit estimates. Standard errors in parentheses.

* denotes coefficient and standard error multiplied by 100 .

$\rho$ indicates the proportion of the total variance accounted for by the panel component. Set of other controls included: Educational qualifications (5 dummies), union presence (membership, coverage), married, male, children, number of employees in household, poor health, temporary contract, white, tenure (4), occupation (8), region (18), year (2). 


\section{References}

Arulampalam, W, Booth, A L and Taylor, M P (2000), 'Unemployment persistence', Oxford Economic Papers, Vol. 52, pages 24-50.

Arulampalam, W, Gregg, P and Gregory, M (2001), 'Unemployment scarring', Economic Journal, Vol. 111, pages F577-584.

Arulampalam, W (1999), 'A note on estimated coefficients in random effects probit models', Oxford Bulletin of Economics and Statistics, Vol. 61, pages 507-602.

Attanasio, O P (1999), 'Consumption', in Handbook of Macroeconomics, edited by J Taylor and M Woodford. Elsevier Science.

Banks, J, Blundell, R and Brugavini, A (2001), 'Risk pooling, precautionary saving and consumption growth', Review of Economic Studies, Vol. 68, pages 757-779.

Benito, A (2001), 'Household-level consumption functions: life-cycle, cohort and aggregate effects in Britain', mimeo, Bank of England.

Browning, M And Crossley, T (1999), 'Shocks, stocks and socks: consumption smoothing and the replacement of durables during an unemployment spell', mimeo, McMaster University.

Caballero, R J (1990), 'Consumption puzzles and precautionary savings', Journal of Monetary Economics, Vol. 25, pages 113-136.

Campbell, J Y (1987), 'Does saving anticipate declining labor income?', Econometrica, Vol. 55, pages 1249-1273.

CARroll, C D (2001), 'A theory of the consumption function, with and without liquidity constraints' Journal of Economic Perspectives, Vol. 15, pages 23-45.

Carroll, C D (1994), 'How does future income affect current consumption?', Quarterly Journal of Economics, Vol. 109, pages 111-148.

Carroll, C D (1992), 'The buffer-stock theory of saving: some macroeconomic evidence', Brookings Papers on Economic Activity, pages 61-156.

Carroll, C D, Dynan, K E and Krane, S D (1999), 'Unemployment risk and precautionary wealth: Evidence from households' balance sheets', mimeo, Johns Hopkins University.

Carroll, C D And Dunn, W E (1997), 'Unemployment expectations, jumping $(\mathrm{S}, \mathrm{s})$ triggers and household balance sheets', NBER Macroeconomics Annual. Bernanke, B E and Rotemberg, J (eds.). MIT Press, Cambridge, MA.

Dynan, K E (1993), 'How prudent are consumers?', Journal of Political Economy, Vol. 101, pages 1104-1113. 
Green, F, Machin, S and Manning, A (1997), 'The employer-size wage effect: Can dynamic monopsony provide the explanation?' Oxford Economic Papers, Vol. 48, pages $433-455$.

Guariglia, A And Rossi, M (2002), 'Consumption, habit formation and precautionary saving: Evidence from the British Household Panel Survey', Oxford Economic Papers, Vol. 54, pages 1-19.

Guiso, L, Jappelli, T and Terlizzese, D (1992), 'Earnings uncertainty and precautionary saving' Journal of Monetary Economics, Vol. 30, pages 307-337.

Hall, R E AND Mishkin, F S (1982), 'The sensitivity of consumption to transitory income: Estimates from panel data on households', Econometrica, Vol. 50, pages 461-81.

Kimball, M S (1990), 'Precautionary saving in the small and in the large', Econometrica, Vol. 58, pages 53-73.

King, M A And Dicks-Mireaux, L-D L (1982), 'Asset holdings and the life-cycle', Economic Journal, Vol. 92, pages 247-167.

Kuehlwein, M (1991), 'A test for the presence of precautionary saving', Economics Letters, Vol. 37, pages 471-475.

Lusardi, A (1998), 'On the importance of the precautionary saving motive', American Economic Review, Papers and Proceedings, Vol. 88, pages 449-453.

Miles, D (1997), 'A household level study of the determinants of consumption and income', Economic Journal, Vol. 107, pages 1-25.

Nickell, S, Jones, P And Quintini, G (2002), 'A picture of job insecurity facing British men', Economic Journal, Vol. 112, pages 1-27.

PAGAN, A (1984), 'Econometric issues in the analysis of regressions with generated regressors', International Economic Review, Vol. 25, pages 221-247.

Pemberton, J (1997), 'The empirical failure of the life cycle model with perfect capital markets', Oxford Economic Papers, Vol. 49, pages 129-151.

Sandmo, A (1070), 'The effect of uncertainty on saving decisions', Review of Economic Studies, Vol. 37, pages 353-360.

Shorrocks, A F (1975), 'The age-wealth relationship: A cross-section and cohort analysis', Review of Economics and Statistics, pages 155-163.

Skinner, J (1988), 'Risky income, life cycle consumption, and precautionary savings', Journal of Monetary Economics, Vol. 22, pages 237-255.

Starr-McCluer, M (1996), 'Health insurance and precautionary saving', American Economic Review, Vol. 86, pages 285-295. 
StataCorp (2001) Stata Statistical Software: Release 7.0. College Station, Texas: Stata Corporation.

Stewart, M B (1990), 'Union wage differentials, product market influences and the division of rents', Economic Journal, Vol. 100, pages 1122-1137.

Stewart, M B (1983), 'On least squares estimation when the dependent variable is grouped', Review of Economic Studies, Vol. 50, pages 737-753.

Taylor, M (ed.) (1999), British Household Panel Survey User Manual Volume A: Introduction, Technical Reports and Appendices, ESRC Research Centre on Micro-Social Change, University of Essex, Colchester.

Zeldes, S P (1992), Comments on Carroll (1992) Brookings Papers on Economic Activity, pages 141-49.

Zeldes, S P (1989), 'Optimal consumption with stochastic income: Deviations from certainty equivalence', Quarterly Journal of Economics, Vol. 104, pages 275-298. 